M. N. IGNATIEVA ${ }^{1}$, Professor, Doctor of Economic Sciences, ief.em@ursmu.ru

V. V. YURAK ${ }^{1}$, Associate Professor, Candidate of Economic Sciences

O. A. LOGVINENKO' ${ }^{1}$, Senior Lecturer

${ }^{1}$ Ural State Mining University, Yekaterinburg, Russia

Knowledge of some principles easily compensates the lack of knowledge of some facts.

(C. Helvetius)

\title{
NATURAL CAPITAL. APPROACHES TO ECONOMIC ASSESSMENT
}

\section{Introduction}

The rapidly changing world around us is constantly changing our notions of it. Spurred and encouraged by the market, some people strive for wealth, others - for a more comfortable living or for both. Production and consumption increase uncontrollably as a result. The change of the idea of necessary to the extent of superfluity, as well as stimulation of consumer demand for new goods and services has altered both the manmade world and the natural bestowed world, and amplified anthropogenic load on nature, its depletion and pollution as a consequence of population upsurge.

The consumer society reached its apogee in the most developed countries at the end of the last century. Having spent a huge amount of both produced and natural resources, the consumer society changes the trajectory of development and entrepreneurial zeal from the global destruction and sometimes total annihilation of nature to the projects connected with restoration and preservation of almost lost or yet undamaged ecosystems. This, in turn, forces specialists to pay attention to economic valuation of natural resources by improving its theory and methodology [1]. Preaching the concept of total economic value (TEV), which is the value of both usability and existence of the nature existence and its gifts [2], the new economic paradigm originated in its classic form quite long ago, in the 1960s, since the famous report to the Club of Rome club has firmly captured the minds of nowadays researchers.

The Rio Declaration (1992) and the Brundtland Report (1998) are considered to be the beginning of the global promotion of this idea. The official transition from adoption of the Declaration and its recognition by the majority of the world community to its implementation was the UN Concept of Sustainable Development (2015) which replaced the Millennium Development Goals of the early 2000s. One of the stated goals of the new concept was to take into account social and environmental restrictions in the use of natural resources and to rethink the generally accepted estimates of macroeconomic development in terms of evaluation of depletion of natural assets similarly to physical assets (produced), and on this basis, to declare priority of eco- and green technologies and products, which means maximum environmental friendliness.
The real implementation of these ideas and the restructuring of the economic mechanism toward the balanced use of natural resources is impossible without technological and institutional changes, radical rethinking of the existing social structure, modification of classical views on the basic economic categories: the cost, the price and the value of natural resources [3]; the level of economic development, national wealth [4], as well as without new methods and techniques to develop the fresh notions, including the notion of natural capital as the most critical factor of economically, socially and environmentally balanced nature management [5].

This article presents the authors' opinion on the processes taking place today in the field of economic relations considered by most experts as Ecological Economics which gradually replaces the concept of Environmental Economics. This means transition from the term "natural resources" to the term "natural capital". The authors make an attempt to consider the causes of such transition and to answer the question whether it is possible to give the most objective economic estimate of natural resources from the standpoint of mainstream economics, national institutional features and modern visions, subject to compliance with fundamental provisions highlighted by the authors as necessary conditions of such estimate implementation.

\section{Materials and Methods}

The theoretical framework for the research is the theory and methods of evaluation and account of natural capital 
and theory of ecosystem services, as well as the concept of TEV. The informational background of the study into economic evaluation of natural capital is the public databases and procedure of economic assessment of natural resources of national and international statistical organizations, in the first place, UNSD, Eurostat, ESCAP, and international financial institutions of IMF and the World Bank. National accounting was addressed using the data from the national statistical organizations, namely, Federal State Statistics Service of Russia (Rosstat) and the Office for National Statistics UK. Methodological substantiation of forest ecosystem accounting was carried out using the official statistical methodology approved by the Ministry of Natural Resources of the Russian Federation [6], as well as the experience gained by the Cadaster Institute in Yaroslavl in natural capital valuation and account using the integrated ecological and economic approach to the system of national accounts.

\section{Results}

\section{Notion of natural capital}

To understand what constitutes natural capital in the modern world, as well as who, how and why evaluates it, it is necessary to trace evolution of the notion. It is certainly required to distinguish between the biological-physical nature and the ethical phase of nature when it is used to obtain benefits. The role of natural factors in economic relations evolved from simple vital consumption of natural wealth in pre-agrarian economy, from the notion of land as the most important factor in production and wealth creation in the agrarian period of development of productive forces, to utilization of natural resources in the industrial economy and to the concept of natural capital in ecological economics typical of the postindustrial society (Fig. 1).

At present, it is expedient to divide the terms according to the same principles that economic theory uses to distinguish between the concepts of resources and capital: resources are the auxiliary means for obtaining benefits from the use of capital. According to R. Constanza and H. Daly, one of the founders of ecological economics, natural capital is the stock of natural resources and ecosystem services that provide the flow of goods and services in the future (1992) [7]. This definition distinguishes between the functions of nature as a factor of production of goods and services and as the economic assets which is the part of the national wealth that has the ability to increase (when reproduced and not used) and decrease (when used intensively in violation of environmental regulations). By the authors' opinion, the use of the term "natural capital" implies not interchangeability but rather complementarity in relation to "natural resources", the possibility of justifying, through cost estimates, a resource-saving approach to the consumption, conservation and accrual of natural resources, which, while adding the economic content with ecosystem services, call for improvement of methodology of economic evaluation.

Theoretical and methodical basis of economic valuation of natural capital

To date, there are certain differences in the interpretation of the term "economic valuation" regarding natural resources and natural capital. It is allowed to identify the notions of economic valuation, value, cost, price, and payment of interest natural resource, and the procedure and final result of assessment are not always differentiated [8]. The nature of changes

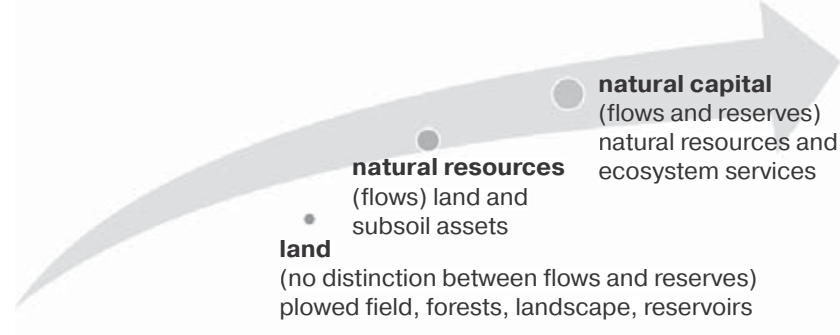

Fig. 1. Evolution of views on natural factor in economic relations

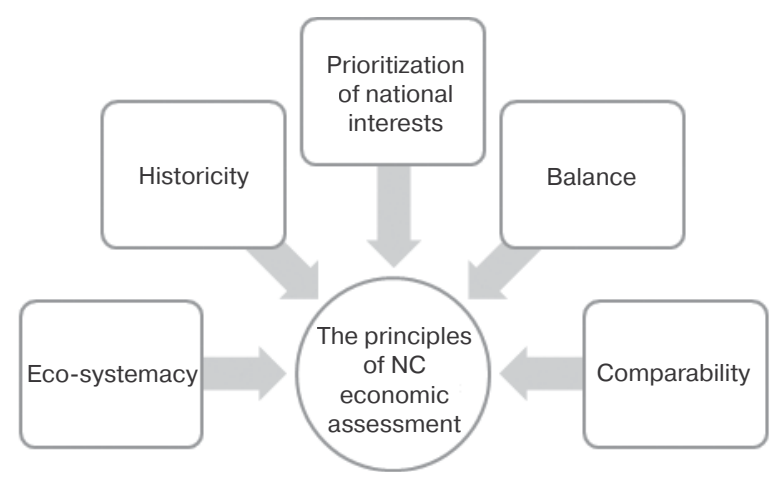

Fig. 2. Principles of economic valuation of natural capital

in generally accepted views on the monetary valuation of natural resources reflects the value concept evolution in economic theory. Historically, the scope of economic valuation of natural resources developed from understanding it as the value which is embodiment of labor costs connected with development and commercialization of natural resources in the early stages to the concept of total economic value that reflects the direct and indirect costs of the use and non-use inherent in modern institutional views on the natural capital that provides the flow of natural resources and ecosystem services.

We agree that the use of the categories "value", "cost" and "price" in relation to natural resources should not interfere but allow various monetary valuation of natural wealth and represent a particular result of economic valuation depending on the tasks being solved as per [9]. Some researchers unequate economic and monetary valuation [10]. We understand the arguments and concerns of adherers to the general monetization of social life, but we believe that any involvement of resources in economic relations a priori implies their cost estimate, and this statement is never challenged in our research.

Economic science has accumulated certain experience in both theoretical justification and practical applications of such estimates. The difficulty of choosing an approach to a methodology for cost estimation individual elements of natural resources and ecosystems in general consists in the required harmonization of the interests of the nation, businessmen and owners of resources, as well as the rights of the population living on the assessed territory or directly related to it. In order that the obtained estimates are not just a set of indicators but the informational background in solving strategic and tactical managerial tasks in integration of results into relevant documents, it is necessary to adhere to the principles of economic valuation of natural capital (Fig. 2). 
The priority of national interests implies inclusion of geopolitical interests in pricing of resources intended for the external and internal markets, or in cost estimates of investment projects and ecosystem services. Historicity means revision of estimates in the changing conditions, for instance, new patterns of utilization of resources, modified technologies, etc. The ecosystem approach implicates selection of the highest priority way of using natural resources with integrated benefit accounting, i.e. not only benefits from the traditional economic relations of the productive functions of nature, but also the entire range of ecosystem services. Consistency of the results should be observable in regional and international assessments, in accounts and estimates at all levels of management, from continuous monitoring at the local and regional scale to the changes in natural capital at the national scale. The balance is achieved based on social, environmental and economic constraints [11].

As noted earlier, the economic valuation of natural resources and ecosystem services must meet a certain range of challenges. The critical challenge is inclusion of natural capital in the national wealth [12]. Becoming an economic asset and bringing certain benefits, raw natural resources and ecosystem services, while transforming into the natural capital, have a significant impact on the size of national wealth of a country in the modern world.

\section{Natural capital and national wealth in the SNA}

Currently, a new technique proposed by the World Bank specialists for valuation of national wealth (NW) in accordance with the expanded model approved by the United Nations (UN) has provoked the great interest. This technique assumes the inclusion of natural resources and ecosystem services in NW as the accumulated natural capital along with traditional (produced) and co-called human capital. The cost estimate and account of natural resources as a component of NW in economic practice is directly related to the system of national accounts (SNA). Given the certain aggregation of the SNA accounts, it is proposed to use the satellite system of environmental and economic accounting (SEEA-2012) for the natural capital accounting in SNA 2008 [13]. In this regard, the experience of countries where the valuation of natural capital has been conducted for several years was utilized. The use of the SNA implies cost estimate of natural resources at market values. Lacking such valuation experience, Russian statistics has some difficulties in accounting for certain natural capital components, in particular, some ecosystem services. However, due to the increasing limitedness of ecosystem services rendered to human beings by nature, their value may be not less but higher than the value of raw materials, which means that their economic valuation as the national wealth is also necessary for society similarly to valuation of the raw material potential. It is difficult to use the market values in the Russian Federation, though positive valuation experience of some countries [14] can be in national accounting in Russia. The cost estimates of mineral raw materials and non-cultivated biological resources as a component of the national wealth were implemented by Rosstat by the time-revenue method using the methodology of the RF Ministry of Natural Resources (Table 1).

According to official statistics, natural capital makes about $14 \%$ in the total value of the country's national wealth. At the same time, the lion's share (90.9\%) in this value is abiotic resources (minerals), or the so-called non-renewable natural
Table 1. Size natural capital in the national wealth of the Russian Federation in 2017, billion rubles*

\begin{tabular}{|c|c|}
\hline The national wealth of Russia & 426469 \\
\hline The natural resources (total), including & 60,764 \\
\hline Minerals & 55,238 \\
\hline Biological resources, including & 5,526 \\
\hline Forest and & $5,525.4$ \\
\hline Animals & 0.6 \\
\hline \multicolumn{2}{|l|}{ *By data from Rosstat [15]. } \\
\hline
\end{tabular}

capital. Renewable or biotic resources are represented only by forest resources assessed as productive wood and by game animals. Other ecosystem services are unevaluated at the national scale. However, a number of works held under the auspices of the United Nations, European Community, other official intergovernmental and private commercial and non-profit organizations, such as the World Bank and WWF, as well as national-level researches on individual regions and ecosystems allow a conclusion that the natural component of the national wealth is extremely underestimated.

The analysis of these works enables, in the first approximation, redistribution of the national natural capital in terms of increment in the renewable part by not less than $15 \%$, which changes the ratio of 90 to $10 \%$ (Rosstat) to 75 to $25 \%$ (the World Bank) [16]. The total value of the RF NW also increases due to the economic evaluation of some environmental and cultural ecosystem services rendered by solely Russian forest ecosystems by not less than $20 \%$ as against the Rosstat's value. What are these figures based on? As noted earlier, inclusion of natural capital in the national wealth in the modern world is predetermined by the very process of development of society and its institutions, as well as by the features of economic relations prevailing in society.

All that nature can offer to a human being, sooner or later, either permanently or for a specified time can convert from an absolute gift, given the excess or lack of demand or due to quantitative and qualitative reduction, to a limited economic resource, which under efficient management and constant account, will be able to make a profit and even increase (in the case of ability to renew in the short term), or reduce down to critical limits and vanish in case of ineffective regulation of consumption. The latter directly relates to forests, which is Russia's natural capital component that is huge (at least physically) and has even greater potential both as an asset capable to increase the size of national wealth and as a flow of ecosystem services that affects the amount of annual monetary income.

Forest is the only ecosystem capable of providing almost all services or so-called human benefits: productive, regulatory and cultural. Countries with high levels of production and even higher levels of consumption, which realized the need for such assessments well ahead the rest of the world, have started to work on economic valuation of ecosystem services and on embedding the value of natural capital in the SNA, and have already achieved certain results. In the Russian Federation, accounting for natural capital in the national wealth is at the early stage of development. At the same time, the existing experience of other countries [14, 17] will hopefully allow us to run this way at minimum loss of time and materials. 
Table 2. Physical and monetary values of natural capital in the UK (2000, 2007 and 2015)*

\begin{tabular}{|c|c|c|c|c|c|c|}
\hline \multirow[b]{2}{*}{ Services } & \multicolumn{2}{|c|}{2000} & \multicolumn{2}{|c|}{2007} & \multicolumn{2}{|c|}{2015} \\
\hline & $\begin{array}{c}\text { Annual } \\
\text { flow }\end{array}$ & $\begin{array}{l}\text { Assets } \\
\text { (stock) }\end{array}$ & $\begin{array}{c}\text { Annual } \\
\text { flow }\end{array}$ & $\begin{array}{l}\text { Assets } \\
\text { (stock) }\end{array}$ & $\begin{array}{c}\text { Annual } \\
\text { flow }\end{array}$ & $\begin{array}{l}\text { Assets } \\
\text { (stock) }\end{array}$ \\
\hline Supply & 24.5 & $\begin{array}{l}\text { No } \\
\text { data }\end{array}$ & 22.7 & 318.77 & 7.84 & 351.75 \\
\hline Timber, $\mathrm{Mm}^{3}$ & 9.8 & & 11.2 & & 13.7 & \\
\hline Billion GBP & 0.1 & 3.58 & 0.16 & 2.87 & 0.23 & 6.3 \\
\hline Minerals, Mt & 303 & & 296 & & 222 & \\
\hline Billion GBP & 0.2 & 0.56 & 0.09 & 3.86 & 0.35 & 10.42 \\
\hline $\begin{array}{l}\text { Oil and gas, } \\
\text { Mt of oil } \\
\text { equivalent }\end{array}$ & 241 & & 151 & & 84.7 & \\
\hline Billion GBP & 19.7 & $\begin{array}{l}\text { No } \\
\text { data }\end{array}$ & 19.1 & 162.04 & 1.16 & 138.27 \\
\hline $\begin{array}{l}\text { Renewable } \\
\text { energy, Mt of } \\
\text { oil equivalent }\end{array}$ & 0.85 & & 1.6 & & 5.6 & \\
\hline Billion GBP & - & - & - & - & 2.8 & 35.85 \\
\hline $\begin{array}{l}\text { Other } \\
\text { (agriculture, } \\
\text { water intake), } \\
\text { billion GBP }\end{array}$ & 4.5 & 166.77 & 3.33 & 150 & 3.3 & 160.95 \\
\hline Regulative & & - & 3.16 & 124.24 & 2.6 & 137.69 \\
\hline $\begin{array}{l}\text { Carbon } \\
\text { sequestration } \\
\text { (removed } \\
\mathrm{CO}_{2}, \mathrm{Mt} \text { ) }\end{array}$ & 22.6 & & 24.8 & & 25.5 & \\
\hline Billon GBP & - & - & 1.33 & 90.68 & 1.55 & 104.85 \\
\hline $\begin{array}{l}\text { Removal of } \\
\text { contaminants, } \\
\text { Mt }\end{array}$ & & & 1.5 & & 1.45 & \\
\hline Billion GBP & - & - & 1.83 & 33.56 & 1.05 & 32.84 \\
\hline Cultural & & & & - & 5.9 & 300.76 \\
\hline $\begin{array}{l}\text { Recreation } \\
\text { in natural } \\
\text { habitat, } \\
\text { million people }\end{array}$ & & & & & 4.3 & \\
\hline Billion GBP & - & - & - & - & 5.9 & 300.76 \\
\hline
\end{tabular}

The Netherlands, Denmark, Canada, Australia and a number of other countries can be considered pioneers of accounting policies in the field of natural capital. However, the most developed system of environmental accounts is the UK economy. Despite the differences in the scale of natural resources owned by Russia's society, the experience of the country with mature accounting policy is interesting from the standpoint of its possible use in the national accounting system. The methodology of the UK on this issue is presented on the website of the Office for National Statistics and assumes maximum orientation to the provisions of the SNA-2008 and SEEA-2012, subject to possible amendment of the accounting policy procedures with regard to priority of national account features and the need to account for certain services in accordance with economic development trends. The country's natural capital accounts contain physical (non-monetary) and monetary values of ecosystem services provided by natural assets. The information on the physical and monetary valuations per
Table 3. Dynamics of absorption capacity (by CO2) of UK ecosystems from 2010 to 2015 *

\begin{tabular}{|l|c|c|c|c|c|c|}
\hline & 2010 & 2011 & 2012 & 2013 & 2014 & 2015 \\
\hline $\begin{array}{l}\text { Million tons } \\
\text { of removed } \mathrm{CO}_{2}\end{array}$ & 25.4 & 25.2 & 23.8 & 25.5 & 26.1 & 25.5 \\
\hline
\end{tabular}

* Compiled by the authors based on data from Office for

National Statistics UK.

Table 4. Forest ecosystems in the value of natural assets secured by UK ecosystems for 2015 (billion GBP)*

\begin{tabular}{|l|c|c|c|}
\hline \multicolumn{1}{|c|}{ Services } & $\begin{array}{c}\text { All } \\
\text { ecosystems }\end{array}$ & $\begin{array}{c}\text { Forest } \\
\text { ecosystems }\end{array}$ & $\begin{array}{c}\text { Percentage of forest } \\
\text { ecosystems in all } \\
\text { ecosystems, \% }\end{array}$ \\
\hline Timber & 6.3 & 6.3 & 100 \\
\hline $\begin{array}{l}\text { Carbon } \\
\text { sequestration }\end{array}$ & 105 & 43 & 41 \\
\hline $\begin{array}{l}\text { Pollution } \\
\text { absorption }\end{array}$ & 33 & 25 & 76 \\
\hline Cultural & 301 & 13 & 3 \\
\hline Total & 445.3 & 87.3 & 20 \\
\hline $\begin{array}{l}\text { * Compiled by the authors based on data from Office for } \\
\text { National Statistics UK. }\end{array}$
\end{tabular}

Table 5. Forest ecosystem services in terms of NC per capita in some countries in 2014 , USD*

\begin{tabular}{|c|c|c|c|c|}
\hline Country & $\begin{array}{c}\text { Natural } \\
\text { Capital }\end{array}$ & $\begin{array}{c}\text { Timber } \\
\text { Production }\end{array}$ & $\begin{array}{c}\text { Other forest' } \\
\text { services }\end{array}$ & $\begin{array}{c}\text { Excess of } \\
\text { non-timber } \\
\text { over timber }\end{array}$ \\
\hline Australia & 180,192 & 1,626 & 50,190 & 30.2 \\
\hline Great Britain & 7,592 & 72 & 403 & 5.6 \\
\hline Canada & 52,438 & 919 & 7,000 & 7.6 \\
\hline Norway & 103,184 & 889 & 4,160 & 4.7 \\
\hline Russia & 46,921 & 910 & 1,587 & 1.7 \\
\hline USA & 216,186 & 626 & 6,158 & 10 \\
\hline * Compiled by the authors (according) to [18]. \\
\hline \multicolumn{5}{|l}{} \\
\hline
\end{tabular}

annual flows and per values of monetary assets with identification of production (supply), regulation and culture services is given in Table 2 .

The Office for National Statistics UK offers data on individual components of natural capital since 1997. Data for 2000 , 2007 and 2015 were selected as reference points for the analysis in order to track the dynamics of changes and the appearance of individual elements of natural capital as accounting units. The point of interest in the presented data is not only the absolute values of indicators, but the fact of their existence, the ratio of the physical dynamics and monetary values, as well as the structure of services. The analysis of the structure of annual flows and of the size of stock in monetary terms in 2015 is reflective of the prevalence non-productive (regulatory and especially cultural) services.

The data in Table $\mathbf{3}$ show the increase in the value of carbon sequestration services mainly due to the changes in the price.

Integrating the data from (Table 4) in the analysis makes it obvious that in UK, despite the modest size of the physical stock, forest ecosystems are able to provide at least $20 \%$ of the ecosystem services in the country's natural capital. 
Table 6. Natural capital value generated by forest ecosystems in coal mining district of the Kemerovo Region*

\begin{tabular}{|c|c|c|}
\hline Services & $\begin{array}{l}\text { Annual value } \\
\text { (stock), million } \\
\text { rubles }\end{array}$ & $\begin{array}{l}\text { Total value, } \\
\text { (asset), billion } \\
\text { rubles }\end{array}$ \\
\hline Production & 62.1 & 2.1 \\
\hline Regulatory & $171,602.5$ & 5,720 \\
\hline Cultural-aesthetic & $13,536.7$ & 451 \\
\hline Total (forest ecosystems) & $185,201.3$ & $6,173.4$ \\
\hline Total (NC of the region) & 226,720 & $7,557.5$ \\
\hline
\end{tabular}

The wood products of forest ecosystem services per capita amounted to GBP 98 (UK population was estimated as 64.8 million in 2015) and non-wood products per capita was GBP 1.259, which is 10 times higher. For additional analytical information, we present calculations for some other countries (Table 5).

The excess cost of non-wood forest products, including carbon storage and air purification services, varies from 5 to 30 times around the world! This figure in the Russian Federation is merely 1.7 times. The notes to the World Bank report on the analysis of the Russian Federation national wealth implies that, first, the cultural services are disregarded from NC of Russia (while these services in the structure of the UK NC are comparable with the cost of the total natural capital of the country) and, secondly, $\mathrm{CO}_{2}$ absorbability of the Russian forests, according to experts of the World Bank, is clearly below the absorbability of forests in Britain and many other countries. It should be noted that the issue of the absorption capacity of forest ecosystems, as the ecosystem service of carbon sequestration from the atmosphere, is highly debatable both in the world and in the Russian scientific community.

Without going into particulars, according to calculations by both Russian and foreign researches using various methods, the amount of carbon absorbed by Russian forests ranges from 210 to 690 million tons per year [19]. The peak values were obtained by an international team of scientists [20]. However, some authors believe that the national reports on the inventory of the Federal Hydrometeorological Service, the carbon balance is underestimated by 350 million tons per year, while the service of $\mathrm{CO}_{2}$ uptake by UK forests solely (in the amount under 25 million tons per year) allowed the national wealth of the country in 2014 to be increased up to GBP 43 billion [21]. Improvement of the carbon uptake assessment procedures is a necessary condition for the economic valuation of regulative ecosystem services in the future. However, event at the minimum estimates of $\mathrm{CO}_{2}$ intake and carbon prices, the value of $\mathrm{NC}$ in Russia will increase significantly given the service is included in the national accounts of national wealth. The same figures are presented by the World Bank specialists [16].

One of the first fundamental case-studies on natural capital valuation in the national practice is the research implemented in a region of Russia by the Cadastre Institute [22]. The economic valuation of cultural ecosystem services is performed using the method of subjective estimate. The productive ecosystem services are valuated using the methods of market estimate and, partly, subjective estimate (Table 6).
These calculations allow arriving to a conclusion on the similar trend in the ratios of forest and non-forest ecosystems, as well as the role of non-wood forest products in terms of regulatory services. Nearly $80 \%$ of the annual value of natural capital comes from forest land. The cost of regulatory and cultural services generated by forest ecosystems is several times higher than the total cost of production and abiotic services in the region. Considering percentage of these services in the value of natural capital in the UK and in other countries with a high value of NC per capita, the development of the valuation procedure in the Russian Federation can contribute to a significant increase in the NC value in the foreseeable future.

\section{Conclusion}

Evaluation of national wealth is one of the economic problems of higher concern in the world. Researches from various countries under the auspices of the UN, EU, nongovernmental environmental organizations and foundations combine their efforts to shape the socio-environmental oriented view of economic sustainable development among politicians and society [23]. The Russian Federation, with its natural resources meeting requirements of both the national and global economies, is no less in need of an effective mechanism for integrated environmental and economic accounting. The experience of other countries, combined with the development of a national institutional framework for the effective environmental management as well as methods for economic valuation of natural capital, not only in terms of natural resources but also ecosystem services, will enable an objective assessment of the country's national wealth. Evaluation of environmental services, such as carbon sequestration and air purification, cultural and aesthetic services in monetary terms, and constant monitoring of cost changes in the size and quality of these services, will make it possible to trace effectiveness of the country's economic policy in the field of natural capital management.

\section{Acknowledgement}

The research was supported by the Ministry of Science and Higher Education under state contract with the Ural State Mining University, Contract No. 075-03-2021-303 dated 29 December 2020.

References

1. Glazyrina I. P. Natural capital in the Economics of Transition Period. Moscow : NIA Priroda, REFIA. 2001. 204 p.

2. Dushin A. V., Yurak V. V. Authors' approach to the Total Economic Value: Essentials, structure, evolution. Eurasian Mining. 2018. No. 1. pp. 11-15. DOI: 10.17580/em.2018.01.03.

3. Logvinenko O. A. Transformation of views on the content and methods of economic assessment of natural resources. News of the Ural State Mining University. 2019. Vol. 4(56). pp. 160-168.

4. Kunt A., Hamilton A., Dixon J., Clemens M. Estimating National Wealth: Methodology and Results. The World Bank, Environmentally Sustainable Development, 1998.

5. Glazyrina I. P. Institutional context of environmental Economics. Institutional transformation of the economy: space and time. 2017. pp. 128-132.

6. Official statistical methodology for assessing the reserves of non-cultivated biological resources : Approved by the Ministry 
of Natural Resources of the Russian Federation, Order No. 448 as of 25.09.2018.

7. Costanza R., Daly H. E. Natural capital and sustainable development. Conservation Biology. 1992. Vol. 6, No. 1. pp. 37-46.

8. Ivanov A. N., Logvinenko O. A., Ignatieva M. N. Economic assessment of environmental consequences in subsoil use. Izvestiya vuzov. Gornyi zhurnal. 2019. No. 6. pp. 98-107. DOI: 10.21440/0536-1028-2019-6-98-107

9. Sosnina T. N. Cost: historical and methodological research. Training manual. Samara State Aerospace University. Samara, 2005. $435 \mathrm{p}$.

10. Kelemen E., García-Llorente M., Pataki G., Martín-López B., Gómez-Baggethun E. Non-monetary techniques for the valuation of ecosystem service. OpenNESS Ecosystem Services Reference Book. 2016.

11. Dumnov A. D., Fomenko G. A., Fomenko M. A. Ecosystem accounting as a further development of the system of integrated natural resource and economic accounting and SNA. Voprosy statistiki. 2015. No. 5. pp. 11-34.

12. Logvinenko O. A., Strovsky V. E. Natural resources from the position of accounting as a part of national wealth. News of the Ural State Mining University. 2019. Vol. 2(54). pp. 126-133. DOI: 10.21440/2307-2091-2019-2-126-133

13. The central basis of the System of Natural-Economic Accounting. New York : UN, 2012

14. Schröter M., Marques A., Tobón W. et al. National ecosystem assessments in Europe: a review. BioScience. 2016. Vol. 66, No. 10. pp. 813-828.

15. Russia in numbers. 2018: Short statistical compendium. Moscow: Rosstat, 2018. 522 p.
16. How wealthy is Russia 2000-2017. Washington, DC : World Bank, 2019.

17. Hein L., Bagstad K., Edens B., Obst C., de Jong R., Lesschen J. P. Defining Ecosystem Assets for Natural Capital Accounting. PLOS ONE. 2016. Vol. 11(11). e0164460.

18. Lange G.-M., Wodon Q., Carey K. The Changing Wealth of Nations 2018 : Building a Sustainable Future. Washington DC: World Bank Group, 2018.

19. Zamolodchikov D. G., Grabovsky V. I., Kurts V. A. Managing the carbon balance of Russian forests: Past, present and future. Ustoichivoe lesopolzovanie. 2014. No. 2. pp. 23-31.

20. Dolman A. J., Shvidenko A., Schepaschenko D., Ciais P., Tchebakova N. et al. An estimate of the terrestrial carbon budget of Russia using inventory-based, eddy covariance and inversion method. Biogeosciences. 2012. Vol. 9. pp. 5323-5340.

21. Filipchuk A. N., Malysheva N. V., Moiseev B. N., Strakhov V. V. Analytical review of methods for emissions accounting and uptake of atmospheric greenhouse gases by forests. Lesokhozyaystvennaya informatsiya. 2016. No. 3. pp. 36-85.

22. Fomenko G. A., Fomenko M. A., Horoshkin K. A., Mikhailova A. V. Accounting and assessment of ecosystem services of Novokuznetsk coal-mining area (Kemerovo Region). Izvestiya RAN. Seriya geograficheskaya. 2019. No. 3. pp. 88-97.

23. Mensah J., Ricart Casadevall S. Sustainable development: Meaning, history, principles, pillars, and implications for human action: Literature review. Cogent Social Sciences. 2019. Vol. 5(1). DOI: 10.1080/23311886.2019.1653531 国 